\title{
Interoperability in e-Government Solutions: The Case of Brazilian Federal Universities
}

\author{
Alberto Dumont Alves Oliveira \\ School of Arts, Sciences and Humanities \\ University of São Paulo \\ Av. Arlindo Bettio, 1000 - São Paulo, SP - Brazil \\ albertodumont@usp.br
}

\author{
Marcelo Medeiros Eler \\ School of Arts, Sciences and Humanities \\ University of São Paulo \\ Av. Arlindo Bettio, 1000 - São Paulo, SP - Brazil \\ marceloeler@usp.br
}

\begin{abstract}
Governments use Information and Communication Technology (ICT) to provide citizens, organizations and governments with online services and tools. One of the key factors in this context is system interoperability, since it promotes the exchange of information among systems in different levels. Achieving high levels of interoperability, however, is challenging because it involves different concepts, business processes, standards, languages, ontologies and laws. The Brazilian government has defined the e-PING Interoperability Standards to specify the guidelines for achieving interoperability in different levels, but many public organizations cannot completely implement the interoperability aspects in their solutions. Therefore, the purpose of this paper is to present an investigation we conducted with the ICT departments of the Brazilian federal universities to understand whether and how they use the e-PING interoperability standards, and what are the main challenges. Results show that most universities do not fully implement interoperability requirements mainly because of a shortage of ICT staff, lack of knowledge and lack of clear instructions on how to achieve interoperability using the e-PING standards. Such findings allow us to identify several improvements on the Brazilian egovernment strategy.
\end{abstract}

\section{CCS Concepts}

- Information systems $\rightarrow$ Web applications • Applied computing $\rightarrow$ Information integration and interoperability

- Applied computing $\rightarrow$ E-government - Software and its engineering $\rightarrow$ Interoperability.

\section{Keywords}

Interoperability; digital government; e-government; e-PING; Brazil.

\section{INTRODUCTION}

The Internet has been extensively used by governments to provide citizens, organizations, tourists and other governments with relevant information and services [25]. This strategic use of Information and Communication Technology (ICT) is known as e-Government [9]. An e-Government system usually supports different public sectors such as Health, Security, Education and

Permission to make digital or hard copies of all or part of this work for personal or classroom use is granted without fee provided that copies are not made or distributed for profit or commercial advantage and that copies bear this notice and the full citation on the first page. To copy otherwise, or republish, to post on servers or to redistribute to lists, requires prior specific permission and/or a fee.

SBSI 2017, June $5^{\text {th }}-8^{\text {th }}, 2017$, Lavras, Minas Gerais, Brazil.

Copyright SBC 2017.
Tourism, for example [13]. Governments must interact with different parties; therefore three different e-Government models have been defined: government to citizens $(\mathrm{G} 2 \mathrm{C})$, government to business (G2B), and government to government (G2G) [23].

The e-Government systems can also be classified in levels, according to their implantation stage: web presence, when information is available to the public usually through a website; interaction, when users can interact with the agencies through online forms; transaction, when users can perform complete transactions online such as to pay taxes or to receive a license or documents, for instance; and transformation, when governments transform the current operational processes to provide more efficient, integrated, unified, and personalized service [1].

Interoperability has been deemed as one of the key factors to reach more mature stages of an e-Government system [6][15] [21][22]. It is the capacity of different people, organizations and systems to cooperate by exchanging data, information and processes. Interoperability may be presented in different dimensions, among them: technical, which connects different systems to exchange data; semantic, which handles the data exchanged and their meaning; and organizational, which captures the scope of inter- and intra-organizational process alignment that is necessary to meet this interoperability goal [12][24].

In 2005, the Brazilian government defined a standard called ePING to promote interoperability in different levels in its solutions [4]. Since then Brazilian e-Government has indeed evolved, but it is still in the 51st position of the United Nations eGovernment ranking, despite being the 9th greater economy in the world [22]. Besides, there are evidences that many public organizations cannot completely implement the interoperability aspects in their solutions [11]. This raises an important question not only for the Brazilian government, but also for those countries that figure in the same positions as Brazil in the United Nations ranking: what prevents governments such as Brazilian's to achieve high levels of interoperability and consequently more eGovernment maturity?

As part of the effort to answer this question, the main purpose of this paper is to present an investigation conducted in the Brazilian public education sector with the aim of understanding how interoperability requirements have been handled by the Information and Communication (ICT) departments and what are the main challenges in this area. Particularly, we have conducted a study with the ICT department of 30 Brazilian federal universities.

The results of this research show that Brazilian e-Government still have a long way to reach better levels of interoperability. In our study, we have found out that in many ICT departments there is a lack of technical people to meet the growing demand for online 
services; many of them do not even know the interoperability standards defined by the Brazilian government, and there are opportunities to definition of a system development method that prioritizes the application of e-PING guidelines, making interoperability a constant concern in all phases of a project.

This paper is organized as follows. Section 2 provides background on e-Government and interoperability in Brazil. Section 3 describes our research method and Section 4 presents our findings. Section 5 discusses challenges for interoperability in the public sector and provides suggestions such as a systems' development method that aims to make more accessible the application of the guidelines of interoperability using e-PING. Section 6 shows related work. Finally, Section 7 presents the concluding remarks and future directions.

\section{DIGITAL GOVERNMENT AND INTEROPERABILITY IN BRAZIL}

E-Government systems are relatively new in Brazil. They were first introduced in 2000, and since then it has been widely used to straight the relationship with the Brazilian citizen and to provide electronic services and transparent access to information. Several agencies, committees, commissions, standards, documents and specific acts have been created to regulate this specific area [7]. The Brazilian e-Government is evolving and, slowly, has been reaching better positions in the ranking of the e-Government Survey conducted by the United Nations. Brazil is in the Upper Middle Income category, and currently occupies the 51 st position in the e-government ranking and the 37 th in the e-participation ranking [21][22].

One of the main issues that slow down the evolution of the Brazilian e-Government is the lack of technical work force. According to a survey conducted by the Brazilian Court of Auditors, also known in Portuguese as TCU, an agency that supervises the actions of the Information Technology departments of the federal government, 350 out of the 440 federal organizations with a well-defined Information Technology department have been facing problems in hiring and keeping IT people. Out of those 350, 39\% have issues in hiring people for specific positions and 75\% face problems in keeping people [19].

The main standards defined by the Brazilian government are the following: e-MAG is an accessibility model for public administration web sites; Digital Government Identity standardizes the digital visual identity and the navigation logic of the government web sites; and e-PING defines a set of policies and technical specifications towards achieving interoperability in government systems [7]. Complying with the standards and rules created by the Brazilian e-Government model is mandatory for all instances of the Information Technology Resources Administration System (SISP, in Portuguese), an organization system which includes all federal agencies. One of the key aspects of the success of e-Government solutions is interoperability requirements. Therefore, Brazilian federal Government has created, in 2005, the Brazilian Electronic Government Interoperability Standards, also known in Portuguese as e-PING. The main purpose of e-PING is to define interoperability guidelines, polices and technical specifications for e-Government systems. It basically establishes the conditions under which all public sectors; the population and the organizations will interact and interoperate their systems [4].
The e-PING is organized in five components: interconnection, which establishes the conditions under which the government bodies interconnect themselves, besides setting the conditions for interoperation between the government and society; security, which deals with the security aspects of ICT that the federal government should consider; means of access, which explains issues related to devices used for accessing e-Government services; organization and exchange of information, which addresses aspects related to the processing and transfer of information in electronic government services; and areas of Integration for Electronic Government, which manages the information exchange between transversal areas and sectors [4].

Table 1 shows examples of the components and key technical specifications distributed over the five segments of the e-PING interoperability standards.

Table 1. An overview of the e-PING [4].

\begin{tabular}{|c|c|c|}
\hline Segment & Component & $\begin{array}{c}\text { Technical } \\
\text { Specification } \\
\end{array}$ \\
\hline \multirow{3}{*}{ Interconnection } & Application & $\begin{array}{l}\text { SMTP, MIME, } \\
\text { LDAP }\end{array}$ \\
\hline & Network / Transportation & TCP, UDP, IPV6 \\
\hline & Link / Physical & IEEE $802.11 \mathrm{~g}$ \\
\hline \multirow{8}{*}{ Security } & Data communication & TLS, IPSec AH \\
\hline & E-mail & HTTPS, SPF \\
\hline & Encryption & RSA, AES \\
\hline & Systems development & $\begin{array}{l}\text { XMLSig, } \\
\text { WS-Security }\end{array}$ \\
\hline & Network Services & LDAPv3 \\
\hline & Wireless networks & WPA2 (AES) \\
\hline & Incident response & $\begin{array}{l}\text { Forensic } \\
\text { Techniques }\end{array}$ \\
\hline & Audit & Ordinance 141 \\
\hline \multirow{3}{*}{$\begin{array}{l}\text { Means of } \\
\text { Access }\end{array}$} & Means of publication & $\begin{array}{l}\text { HTML 5, XML, } \\
\text { ODT }\end{array}$ \\
\hline & Mobile & W3C Best Practices \\
\hline & Digital TV & $\begin{array}{l}\text { ABNT NBR } 15601 \\
\text { to } 15610\end{array}$ \\
\hline \multirow{2}{*}{$\begin{array}{l}\text { Organization } \\
\text { and Exchange }\end{array}$} & Treatment and transfer & $\begin{array}{l}\text { XML, JSON, } \\
\text { EDGV }\end{array}$ \\
\hline & Vocabularies / Ontologies & RDF, OWL \\
\hline \multirow{3}{*}{$\begin{array}{l}\text { Integration } \\
\text { Areas }\end{array}$} & $\begin{array}{l}\text { Cross-cutting themes for } \\
\text { government areas }\end{array}$ & BPMN, BPEL4WS \\
\hline & Web services & $\begin{array}{l}\text { WSDL, SOAP, } \\
\text { HTTP }\end{array}$ \\
\hline & Enterprise Architecture & FACIN Framework \\
\hline
\end{tabular}

Alongside with interoperability standards, the Brazilian government has also been investing in means to promote interoperability, such as the Open Data National Infrastructure (INDA, in Portuguese), which is the open data specification and policy based on the e-PING; the Ontology and Vocabulary for eGovernment (e-VoG, in Portuguese), which comprises standards, tools and repositories to exchange semantic information; and the Controlled Vocabulary of Electronic Government (VCGE, in Portuguese), a special vocabulary related to different subjects whose purpose to achieve more effective information and service presentation [7]. 
A new framework called Brazilian Government Enterprise Architecture Framework to support Governance and Interoperability (FACIN, in Portuguese) is under development as part of the federal Digital Governance Strategy [7]. This framework is based on the TOGAF 9.1 framework, but adapted to the Brazilian government context. The main purpose of the FACIN is to create a consistent model to represent the capabilities of each governmental organization. Frameworks for corporate architecture are used by several governments as they provide a set of structures, methods and tools for the development of enterprises information technology architectures. The major frameworks found in the literature are The Open Framework Architecture Framework (TOGAF) and The Zachman Enterprise Framework [16][20].

FACIN comprises nine views that are related to all corporative environments: strategy, governance, risk and conformity, business, data, applications, infrastructure, security, programs and projects, and society. Those views can interact with each other. For example, security is spread through all views, and infrastructure supports other views physically and digitally. This framework is supposed to be officially released in 2017, as part of many advances accomplished by the Brazilian Digital Governance Strategy [14].

\section{METHODS AND DATA COLLECTION}

The main purpose of this study is to present an investigation conducted in the Brazilian public education sector with the aim of understanding how interoperability requirements, policies, rules and specifications have been handled by the Information and Communication (ICT) departments and what are the main challenges in this area. The objects of our study are the Brazilian federal universities for two main reasons: few studies approach the e-Government status in upper middle income countries such as Brazil, Argentina, Colombia, Mexico and China, for example [22]; and universities tend to grant researchers more access to conduct research than other kinds of federal organizations, mainly due to bureaucracy.

There are currently 63 federal universities in Brazil, which are also known as Federal Higher Education Institutions (IFES, in Portuguese) [10]. They are all part of the Federal Public Administration and they are bond to the Information Technology Resources Administration System (SISP, in Portuguese). Therefore, as mentioned before, they must comply with the standards, laws and rules defined by the federal government [7].

We conduct our research in three steps. At first, we conducted a qualitative case study in one federal university to identify real scenarios in which issues related to interoperability in eGovernment portals and systems may emerge. We also wanted to know how the ICT department of this university complies with the standards, laws and rules defined by the federal government with respect to interoperability. The case study was conducted in the ICT department of this university by means of interviews, ethnography and a thorough analysis of the resources available.

Next, in a quantitative approach, we have applied a survey ${ }^{1}$ directed to the employees of the ICT department of the 63 Brazilian federal universities. The survey questions was

1 The survey questions are not presented here for space limitations. It is available on the link https://goo.gl/1asZ8b elaborated based upon the information gathered in the first step of this study. It has 16 questions split in three sections: eGovernment, to gather information regarding the level and quantity of services they provide; systems interoperability, to understand whether and how they comply with the interoperability standards; and software development process, to find out what are their approach to develop e-Government solutions.

In the last step, we summarized and analyzed all data obtained from the applied survey. The outcome of this analysis is a list of the main issues related to meeting the interoperability requirements defined by the federal government through e-PING standards. We believe that this study give important insights to propose improvements in this context.

\section{FINDINGS IN BRAZILIAN FEDERAL UNIVERSITIES E-GOVERNMENT}

Each Brazilian federal university may have its own organizational structure and strategies to fulfill their purposes as a higher education institution. Nonetheless, all of them are subject to the same rules, standards and laws published by the Brazilian government. In this section, we show a detailed analysis and a case study conducted in a Brazilian federal university (Subsection 4.1). We used this case study to devise a survey that has been directed to all Brazilian federal universities. Employees of 30 Brazilian federal universities answered the survey and the results and analysis are presented in Subsection 4.2.

\subsection{A Case Study in a Brazilian Federal University}

Federal University of Uberlândia is a Higher Education Institution that offers 93 undergraduate courses, 54 postgraduate programs and several other courses. This university has administrative and academic units: one rector and vice-rector, six pro-rectors, six higher councils, 15 administrative agencies, four school hospitals, and 32 academic units. It also has approximately 24.500 students, 1.670 professors, 3.038 administrative staff, as well as outsourced staff and large external community [3]. This Brazilian federal university has an Information Technology Center department responsible for managing and implementing ICT resources. This department has 63 employees distributed in three sectors: infrastructure and networks; systems; and technical support [5].

System sector has 22 ICT analysts, 58 systems, approximately 600 web portals, and a continuing demand for new software and web portals to interoperate and exchange data and information in several areas: academic management, administrative management, financial management, people management, wealth management, purchasing and transportation management, document management, creation of web portals for various activities, such as events, research groups, research laboratories, among others [2]. The ICT team, however, is relatively small to such a demand. In addition to the demand for new software and web portals, one of the aggravating factors for the ICT department is the reconstruction of web portals that have outdated technologies.

An analysis of the ICT department and the services provided for internal and external communities' shows that this university eGovernment falls into level 3 since users can perform transactions on-line, such as enrollment for selective processes and courses. Regarding the interoperability level, this university fits in 
dimension 1 - technical, since it can interoperate data between portals through eXtensible Markup Language (XML) and JavaScript Object Notation (JSON) standards.

Web portals are important resources of this university; hence we have analyzed their development process. They follow these steps: interview and meetings with clients for requirement elicitation; planning and design; development; testing; content migration if there is an existing web portal to rebuild; training for users who will manage content; delivery and publication. This whole process can last from 1 to 9 months, depending on the size of the project and the availability of the web project team, which is composed of only five ICT analysts. Due to high demand, a small web project team and deadlines to comply, the Federal University of Uberlândia focuses on delivering the product on time, which does not allow following fully guidelines of the ePING interoperability standards. However, whenever identified, the public organization tries to inter-operate data to avoid duplication of information.

Due to non-full interoperability, one of the major problems at this university is replication of equal data in different publication sources, which also causes slow processes, because the user often finds erroneous or outdated information. Figure 1 depicts an illustration of an ideal scenario following the e-PING guidelines. The components of this fully interoperable architecture exist, but they are not exchanging data as described in this architecture.

Currently, there are few web portals, such as events and news, fully interoperating with several other web portals, but the Enterprise Service Bus to interoperate data from different systems has been used in only one sector of the university so far. However, the plan is to adopt this architecture to allow the fully interoperation among web portals, systems and users. Figure 1 generically illustrates current scenario of web portal interoperability in the institution and a perspective of an ideal scenario following e-PING guidelines.

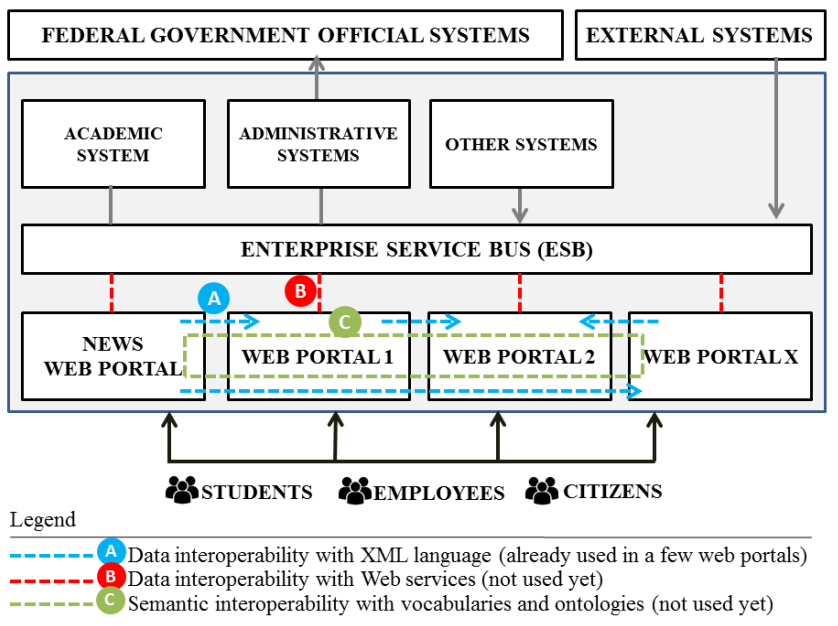

Figure 1. Interoperability in a Brazilian Federal University.

Technically, there are several ways to implement this solution. Content Management System such as Drupal or Plone can provides important resources to reach interoperability functionalities proposed in e-PING. XML and JSON are constantly used for data interoperability between web portals or even to provide data to mobile applications. There are plans to use web services with an ESB to provide software data for use in web portals and systems. There is also the possibility of using the Interoperability Framework (FACIN, in Portuguese), to be made available by the federal government in 2017. In future projects, Web Ontology Language (OWL) and Resource Description Framework (RDF) can be used to provide semantic interoperability.

The goal of this proposal is to concentrate the data only in systems and web portals semantically responsible for their information and then interoperate the necessary data and information with several web portals, promoting the interoperability determined in the e-PING interoperability standards.

\subsection{An Overview of Interoperability and e- Government Levels in Brazilian Federal Universities}

We devised a survey to understand the e-Government and interoperability level and issues related to the solutions implemented in the Brazilian federal universities. The survey was first applied as a pilot conducted with three ICT professional of Federal University presented in the case study. Then we make adjustment and directed the survey to all 63 federal universities spread through the five regions of Brazil [10]. We have got answers from ICT employees of 30 universities, representing the five regions ( 3 from the North, 8 from the Northeast, 3 from the Midwest, 8 from the Southeast, and 8 from the South).

Although these submissions do not represent the institution's official position, they reflect the institution's current situation in the view of people who are working directly in their ICT departments. It is important to highlight that around $40 \%$ of the respondents has management positions, while $60 \%$ has operational positions. Following we summarize the results of the survey in three sections: e-Government, interoperability, and system development.

\subsubsection{E-Government}

Figure 2 shows results on the e-Government level (a), the existence of one stop services center web portal (b) and the quantity of web portals (c). On the level of e-Government, which is the organization's maturity in providing digital solutions, $71.9 \%$ (46 submissions) are at level 3, transaction, in which it is possible to offer some services completely online, such as enrollments and events registrations. A significant number of universities still do not offer a one stop services center web portal with all of institution's online services. $53.1 \%$ (34 submissions) claim to have this web portal, but we found out that ten of them offers a web portal with only static information or one in which not all services are available.

Regarding the quantity of web portal, most institutions $(40.6 \%$ 26 submissions) have declared the existence of 1 to 50 web portals, but an expressive number declared to have more than 300 web portals. This numbers highlights the importance of having interoperability solutions to avoid problems such as data duplication or process slowness. 

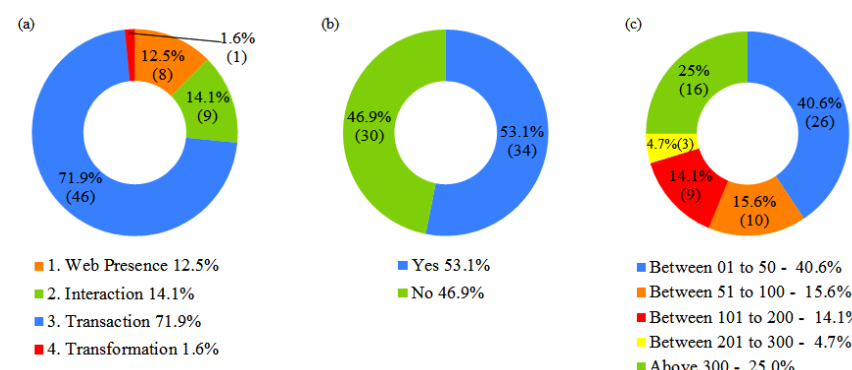

-Between 01 to $50-40.6 \%$ Between 51 to $100-15.6 \%$ - Between 101 to $200-14.1 \%$ Between 201 to $300-4.7 \%$ Above $300-25.0 \%$

Figure 2. e-Government level (a), one stop services center web portal (b) and quantity of web portals (c).

We asked the participants to pick one or more challenges they face on providing online services in Brazilian federal universities. Figure 3 summarizes their answers. Notice that "Reduced or insufficient ICT staff" and "High demand" have been selected as the main challenges to provide online services.

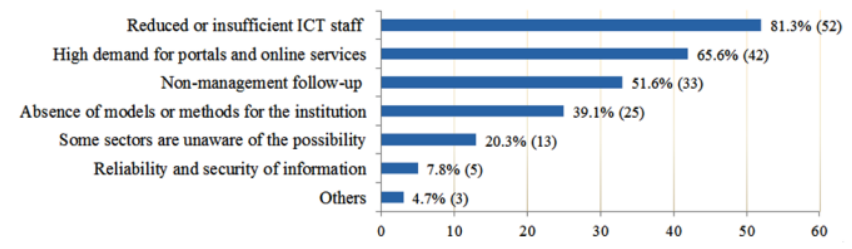

Figure 3. Main challenges to provide online services.

\subsubsection{Interoperability}

Figure 4 presents interoperability levels (a) and the use of e-PING interoperability standards in federal universities (b), which shows, for example, the institution's maturity in having interoperable solutions and consequently a more cohesive and sustainable eGovernment. Results show that most universities, 87.5\% (56 submissions), are at level 1 , technical, in which it is only possible to inter-operate data at a basic level, using, for example, XML and JSON languages, without working at semantics and the meaning of information. Despite government's efforts, 34.4\% (22 submissions) stated that they did not know about e-PING and only $4.7 \%$ (3 submissions) stated they use e-PING integrally.
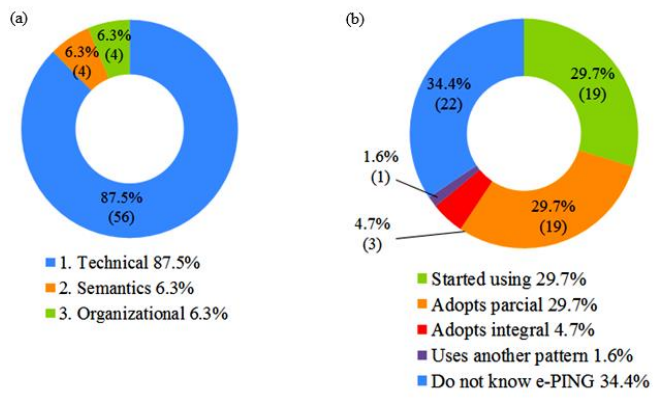

Figure 4. Interoperability levels (a) and use of e-PING (b).

We asked the participants to select one or more resources and technologies they use from e-PING documentation to promote interoperability. Figure 5 shows an overview of the usage of principal artifacts of the three scoop segments of e-PING in this research: means of publication (a), organization and exchange (b) and integration (c). Concerning the publication segment, HTML 5 language is the most used (57.8\% - 37 submissions). In the organization and exchange segment, XML language is the most used $(67.2 \%$ - 43 submissions). Also in this segment, no institution has declared use of ontologies via Simple Knowledge Organization System (SKOS) or Web Ontology Language (OWL). In integration segment, Web Services Description Language (WSDL) feature is the most used $(37.5 \%-24$ submissions).

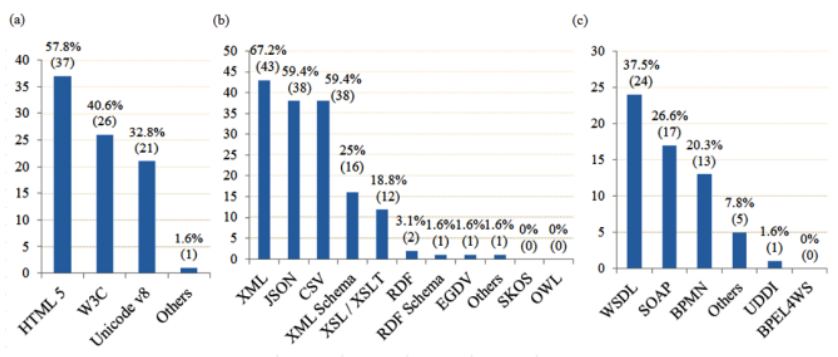

Figure 5. Usage of principal artifacts of e-PING.

We asked the participants to select one or more consequences of the lack of a proper implementation of interoperability requirements. Figure 6 shows the results. Notice that the two main problems are "Slow process" and "Duplication of data and information". Around $50 \%$ of the respondents said that there are other serious consequences, such as problems in promoting transparency and providing access to information that should be available by law. Therefore, poor interoperability leads not only to technical but also to law issues.

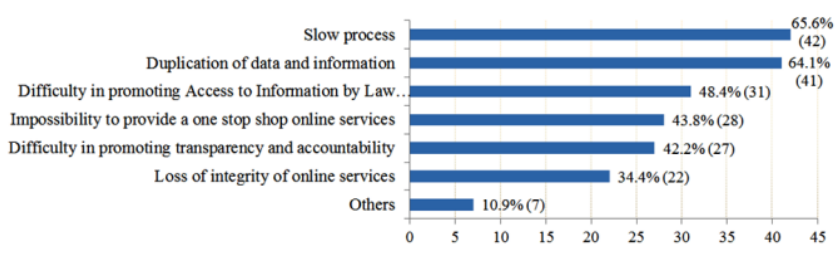

Figure 6. Main problems due to lack of interoperability .

Partıcıpants were askea to seıect one or more cnallenges tney race to fully use the e-PING interoperability standards proposed by the federal government. Figure 7 presents the results. Notice that there is much room for improvement in this area. Most participants said that reduce staff is the major problem, but also that the team's lack the proper skills to implement interoperability requirements. Also, important remarks are the lack of a clear software development process in the institutions and a method or a guide to implement the e-PING requirements. There seems also to be a lack of auditing on the government side to assure every institution is using the correct standards and following the law.

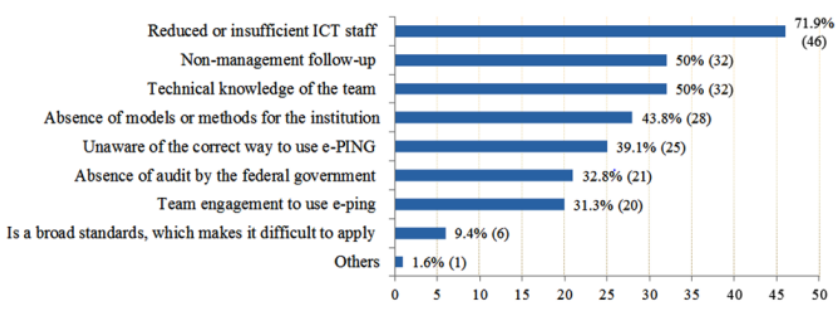

Figure 7. Main challenges to adopt e-PING.

\subsubsection{System Development}

The participants were asked to inform the development process method used in the institution. 59.4\% (38 submissions) of the 
respondents said the development method depends on the project, and around $38 \%$ said to use traditional methods, while nearly $28 \%$ stated to use agile methods. Regarding management frameworks, $45.3 \%$ (29 submissions) uses Scrum, 25\% Kanban and 25\% PMBOK/PMI.

The two final questions of our survey were intended to discover whether the ICT departments of the institutions are aware and use the most recent resources that have been announced by the federal government. 39.1\% (25 submissions) of the participants stated they use Federal Government Electronic Information System, software to support processes and digital documents, $60.9 \%$ (39 submissions) said they don't use it, of these, $20.3 \%$ (13 submissions) use others systems. Regarding the Brazilian Government Enterprise Architecture Framework to support Governance and Interoperability (FACIN, in Portuguese), 93.8\% (60 submissions) said they are not aware of this framework.

\section{DISCUSSION}

The case study we have conducted at the Federal University of Uberlândia and the subsequent survey answered by ICT employees of 30 federal universities show that Brazilian federal universities have common characteristics. First, they have administrative autonomy, but they must comply with the eGovernment standards, patterns and laws defined by the Brazilian government. They all have many institutional web portals and provide several electronic services for different types of users.

Unfortunately, they all seem to share the same problems in providing e-Government solutions in a satisfactory level. The main reason, as pointed out by around $80 \%$ of the respondents, is the reduced or insufficient number of ICT staff. In fact, there is a shortage of ICT professionals in Brazil in the public agencies of the Federal Government. A report from the Brazilian Court of Auditors points out that Federal Public Administration has been facing several challenges in hiring and retaining ICT staff [18][19].

The high demand for new web portals and electronic services is also a common issue shared by several institutions. On top of that, several web portals and services are outdated and need to be updated, which is very difficult due to the staff shortage. This clearly leads to a situation in which the development teams become so overload with several tasks that there is no time for learning how to better create web portals and services such that they can easily inter-operate and be maintained. In fact, $50 \%$ of the respondents stated that the team's lack technical knowledge, and around $40 \%$ said that they do not have a proper model or process to follow when developing software. Even though there is a guideline such as the e-PING interoperability standard, they don't know and they don't have time to learn (40\%).

In such a scenario, it is not surprising that only one respondent stated that they provide e-Government services at its full level transformation, while around $72 \%$ are at level 3 - transaction, and around $27 \%$ are at level 1 and 2 , web presence and interaction, respectively. It is not a surprise, as well, that around $88 \%$ of the respondents said that they provide interoperability in its first level - technical, where data interoperability predominates using basic features such as eXtensible Markup Language (XML). Regarding the e-PING interoperability standards promoted by the Brazilian government, only around 5\% use it integrally, while 30\% adopt partially, 30\% just started using, and many respondents (around $35 \%$ ) didn't even know the interoperability standards, which indicates a serious problem in communication and in Brazilian federal government in assuring that the federal agencies comply with the standards, laws and policies defined at strategic levels.

The scenario of the ICT departments described in our investigation gives clear indications that there is a need for several improvements to increase the level and the maturity of the e-Government solutions in Brazilian federal universities. According to our evaluation, there are some directions in which investments should be made to pursue such a purpose.

The first and most immediate thing to do is hiring more technical staff to fill the gap between the ICT team's sizes and the large demand for new web portals and electronic services. The second and yet urgent action is to invest in training. The ICT teams need to learn how to implement the best e-Government solutions following the best development methods and good practices, and, at the same time, complying with rules, laws, patterns and standards defined by the Brazilian government. In view of amortizing those investments, it is important retain the staff and keep the new workers after they become fully productive, since there are strong possibility of new projects in the universities.

Hiring ICT staff to meet the high demand may not be a practical and realistic solution given the budgetary schedule of most Brazilian federal agencies and universities, which is the case of many lower middle income countries. Therefore, the correct and fully use of interoperability can help to mitigate the situation since interoperability can promote sustainable development by reusing existing solutions, data and information.

In this context, since $39.1 \%$ of the respondents said they don't know how to implement interoperability let alone apply the ePING standards, one important measure to improve Brazilian eGovernment is to define a method to help developers to fully implement the interoperability requirements as defined by the five e-PING segments, making interoperability a constant concern in all phases of a project. The definition of an e-PING focused development method could help such institutions to understand the broad standards, focusing only on what is needed to interoperate data and information between systems, which is one of the key factors to provide more mature e-Government systems. Still in this regard, it is essential to create an ontology that considers the scenario in which Brazilian federal universities can exchange semantically correct information, instead of interoperating only technical data.

Beyond these practical solutions, there are several other actions that could be taken to improve Brazilian e-Government in a broader level. Brazilian Government Enterprise Architecture Framework to support Governance and Interoperability (FACIN, in Portuguese) has been a great bet by the federal government, however, our investigation showed that only $6.2 \%$ are aware of this important resource. For FACIN and other frameworks and standards to succeed, the Brazilian government's communication department needs to be improved. Also, there must be some action plan to assure that all organizations are committed to provide e-Government solutions with excellence. Unfortunately, around $30 \%$ of the respondents stated that the e-PING interoperability standards are not used due to the absence of inspection and control, and $30 \%$ due to team engagement with the objectives of the e-PING.

We also believe that a better approach could be used to reuse solutions or part of solutions within the same institution or even 
across institutions. The several inner sectors of a Brazilian federal university tend to have very similar demands in terms of web portals and electronic services, and it seems that, even though they share several characteristics, a lot of effort is put into every request as if they were unique requests, when a good project management strategy could identify common features and try to optimize the development and the maintenance of several resources. Beyond that, the demands of a Brazilian federal university are only slightly different from one to another. Therefore, we claim that universities should reuse solutions from other universities, which would avoid spending a lot of money and effort to create the same solutions for a problem that has been solved by other university.

Even though this investigation has been done in the education scenario, we believe several of our findings could be applied to other sectors such as tourism, health, safety, and so forth. Therefore, the same suggestions and methods proposed here would be useful in such domains. We believe the most important contribution of our investigation is to highlight the urgent need of investments in this area, so the Brazilian universities can comply with the highest standards of e-Government and interoperability solutions.

\section{RELATED WORK}

Several researches have been investigating how to overcome challenges related to interoperability in the e-Government context, and how to make these environments more efficient and effective for their users. Musafir and Freitas analyzed the strategic direction of the Brazilian e-Government Program from 2008 to 2014 associated with the Brazilian ranking on the United Nations e-Government Survey. Because of those strategies, Brazil moved up 40 positions on the on-line index of the UN Survey from 2010 to 2014 [11].

Their work emphasizes political issues that have been beneficial to the evolution of Brazilian e-Government System, such as the last presidential term was more focused on promoting interaction between government and society. Despite the improvement in online service offerings, the increase of transparency, the usage of open data by the states and cities, and the access provided to public information, Brazil's e-Government index ranking in the UN Survey is advancing very slowly and it still did not regain the 45th global position it had in 2008 [11].

Silveira et al. assessed the Brazilian e-Justice Interoperability Model, an interoperability model created and used by the 91 courts of law in Brazil. The paper proposes improvements to the model based on interoperability levels. According to the authors, the model would achieve higher quality if it were coupled with the existing Brazilian e-Government Interoperability Standards (e-PING). The study also suggests the creation of a documentation containing the policies use and life cycle of the model to improve the maintenance and reuse of the solution [17].

Klischewski and Askar presented a case study in Egypt, a lower middle income country [22]. The paper outlines methods for developing services linked to interoperability governance. The authors discuss the main changes in the development method to obtain interoperability in $\mathrm{G} 2 \mathrm{G}$ and also used Service-Oriented Architecture (SOA) as the main resource for interoperability. The case study revealed significant propositions for success factors in the methodology for developing services with interoperability [8].
Our paper proposes the continuity of these researches involving interoperability and strategies for e-Government solutions. As a differential, this article aims to show how is the usage scenario of the main Brazilian e-Government Interoperability Standards (ePING), and raise a discussion about the possible ways to improve the quality of Brazilian e-Government, especially in public organization that have structural limitations, such as the Brazilian federal universities, which reported having insufficient ICT staff to reach all the demands.

The Brazilian Court of Auditors has published a report about ePING interoperability standards, in which it questions whether the institution uses e-PING, but they present only the following alternatives: "Initiated plan", "Partial use" and "Adopt integrally" [18]. We consider this report very important, but it only considered answers from the head of the ICT department. In our investigation, however, we took into consideration the answers from both the operational and the managerial level people. Furthermore, we added the following alternative to the question related to the use of the e-PING interoperability standards: "Do not know e-PING", which has been chosen for around $35 \%$ of the respondents, even though that e-PING has more than 10 years.

\section{CONCLUDING REMARKS}

This paper presented a brief introduction to the Brazilian eGovernment, including an overview of some standards created to guarantee the implementation of effective and efficient eGovernment systems, and an investigation we carried out to understand how e-Government solutions have been developed in the scenario of Brazilian federal universities, especially when it comes to interoperability aspects. The results show that, despite the efforts made by the Brazilian federal government and the universities we analyzed, there is still a long way to through to achieve higher quality e-Government and sustainable development through to reuse of data and the full interoperability of systems.

Suggestions have been made to improve the issues related to interoperability and the quality of Brazilian e-Government. But establishing interoperability requirements is still a major challenge in e-Government. Each country or region creates and adopts a specific model. Just over 10 years ago, Brazil's instituted the Brazilian Electronic Government Interoperability Standards (e-PING). However, its full utilization is still not a reality. Despite the existence of basic documents and guidelines, system interoperability is complex because it involves concepts, protocols, languages, and other resources. Practical methods and examples that show how to use the e-PING standard are missing.

Our research in education area at Brazilian federal universities may be useful to understand how other government areas such as health, safety and transport, may be facing similar problems. The insufficiency of ICT professionals and their high turnover, the lack of knowledge of laws and standards for Brazilian eGovernment and the lack of communication between government agencies are some identified negative factors.

As future work, we will devise a method that guides developers in considering interoperability aspects of the five segments of the ePING at each step of the development process, since the requirements elicitation until the service delivery and maintenance. Interoperability can promote sustainable development by reusing existing solutions, data and information. Thus, we believe this is a practical solution to many of the 
problems faced by the Brazilian federal universities and possibly by several sectors that cannot comply with the e-PING requirements because they do not know how to use it properly.

\section{REFERENCES}

[1] Baum, C., and Di Maio A. 2000. Gartner four phases of egovernment model. Gartner Group.

[2] CTI. 2016. Centro de Tecnologia da Informação da Universidade Federal de Uberlândia. Available: http://www.cti.ufu.br. Accessed on: Jan., 20, 2017.

[3] CONSUN. 2012. Resolução $N^{o}$ 01/2012 do Conselho Universitário da Universidade Federal de Uberlândia. http://www.reitoria.ufu.br/Resolucoes/ataCONSUN-20121.pdf. Accessed on: Jan., 20, 2017.

[4] E-PING. 2016. Padrões de Interoperabilidade em Governo Eletrônico - E-PING. Available:

http://eping.governoeletronico.gov.br. Accessed on: Nov., 20, 2016.

[5] Federal University of Uberlândia. 2016. Portal da Universidade Federal de Uberlândia. Available: http://www.ufu.br. Accessed on: Nov., 20, 2016.

[6] Gartner. 2015. Gartner Highlights Top 10 Strategic Technology Trends for Government. Available: http://www.gartner.com/newsroom/id/3069117 Accessed on: Mar., 20, 2016.

[7] GovBR. 2017. Programa de Governo Eletrônico Brasileiro. Available: http://www.governoeletronico.gov.br. Accessed on: Jan., 20, 2017.

[8] Klischewski, R and Askar, E. 2012. Linking service development methods to interoperability governance: The case of Egypt. Government Information Quarterly. v. 29. pp. $\mathrm{S} 22-\mathrm{S} 31$.

[9] Marzullo, F. P. 2009. SOA na prática: inovando seu negócio por meio de soluções orientadas a serviços. São Paulo: Novatec Editora, 2009.

[10] MEC. 2016. Ministério da Educação: Sistema e-MEC. Available: http://emec.mec.gov.br. Accessed on: Mar., 11, 2016.

[11] Musafir, V. E. N and Freitas, C. S. 2015. Brazilian eGovernment Strategies. Proceedings of the 15th European Conference on e-Government. University of Portsmouth, UK. pp. 197-197.

[12] Novakouski M. and Lewis, G. A. 2012. Interoperability in the e-Government Context. Available: http://www.sei.cmu.edu/reports/11tn014.pdf. Accessed on: Sep., 11, 2016.

[13] Pappel, I and Pappel, I. 2011. Implementation of servicebased e-government and establishment of state IT components interoperability at local authorities. Proceedings of the 3rd International Conference on Advanced Computer Control (ICACC). pp. 371-377.

[14] Participa.br. 2016. Framework de Arquitetura Corporativa para Interoperabilidade no Apoio à Governança. Available:
http://www.participa.br/articles/public/0019/6143/FACIN_2 016_01_11_Final.pdf Accessed on: Mar., 20, 2016.

[15] Ojo, A and Janowski, T and Estevez, E. 2009. Semantic Interoperability Architecture for Electronic Government. Proceedings of the 10th Annual International Conference on Digital Government Research: Social Networks: Making Connections Between Citizens, Data and Government. pp. 63-72.

[16] Sedek, K. A and Sulaiman, S and Omar, M. A. 2011. A systematic literature review of interoperable architecture for e-government portals. Proceedings of the 5th Malaysian Conference in Software Engineering (MySEC). pp. 82-87.

[17] Silveira, L. and Wazlawick, R. S and Rover, A. J. 2015. Assessing the Brazilian e-Justice. Proceedings of the 2015 IEEE Latin America Transactions, v.13, n.5.

[18] TCU. 2014. Tribunal de Contas da União - Levantamento de governança de tecnologia da informação. Available: http://portal.tcu.gov.br/comunidades/fiscalizacao-detecnologia-da-informacao/atuacao/perfil-de-governanca-deti. Accessed on: Jan., 20, 2017.

[19] TCU. 2015. Tribunal de Contas da União - levantamento do pessoal de tecnologia da informação. Available: https://portal.tcu.gov.br/biblioteca-digital/levantamento-naarea-de-pessoal-de-ti-da-administracao-publica-federal.htm. Accessed on: Jan., 20, 2017.

[20] The Open Group. 2016. Welcome to TOGAF® Version 9.1, an Open Group Standard. Available:

http://pubs.opengroup.org/architecture/togaf9-doc/arch/ Accessed on: Oct., 24, 2016.

[21] United Nations. 2014. e-Government for the future we want. New York: UN, 2014. Available: http://unpan3.un.org/egovkb/Portals/egovkb/Documents/un/2 014-Survey/E-Gov_Complete_Survey-2014.pdf. Accessed on: Dec, 7, 2016.

[22] United Nations. 2016. e-Government in support of sustainable development. New York: UN, 2016. Available: https://publicadministration.un.org/egovkb/enus/Reports/UN-E-Government-Survey-2016. Accessed on: Nov., 3, 2016.

[23] UNPAN. 2010. Government to E-Government to E-Society. Available:http://www.unpan.org/Library/MajorPublications/ UNEGovernmentSurvey/PublicEGovernanceSurveyintheNe ws/tabid/651/mctl/ArticleView/ModuleId/1555/articleId/223 05/Government-to-Egovernment-to-Esociety.aspx. Accessed on: Sep., 18, 2016.

[24] UNPAN. 2016. United Nations Public Administration Network: e-Government Interoperability. Available:http://www.unpan.org/ELearning/OnlineTrainingC entre/EGovernmentInteroperability/tabid/1415/language/enUS/Default.aspx. Accessed on: Sep., 18, 2016.

[25] Vieira, A. C. G. 2009. Melhorando o Acesso ao Governo com o Melhor Uso da Web. São Paulo: W3C Brasil. 